\title{
Environmental Impact Reduction from Using Local Natural Construction Materials: Case Study in the North of Portugal
}

\author{
P. Mendonça and B. Martins
}

\begin{abstract}
The environmental concerns of the building industry in Portugal have been essentially related with the reduction of economic costs by the energetic optimization of materials production and construction processes. This strategy is focused on using prefabricated industrial materials and maximizing the use of mechanized construction methods. However, with the economic crisis, rising energy costs, rising unemployment and lack of skilled professionals due to emigration, decreased demography and ageing of population, the construction sector faces new challenges. The interest on the refurbishment of existing buildings, as well as on recovering traditional techniques is growing, namely by the use of local less transformed materials in buildings. This paper aims to characterize the availability of inorganic natural materials, such as weathering granitoids for adobe and rammed earth solutions and granite stone in the north of Portugal. The objective is to demonstrate that the use of local natural materials in alternative to conventional industrialized materials can present significant economic and environmental potential related with environmental and economic aspects, using a case study research in the north of Portugal. Considering a reference dwelling with a conventional exterior wall solution in hollow brick, it was evaluated the potential environmental savings of changing the brick of the exterior wall solutions by adobe and granite.
\end{abstract}

Index Terms-Construction materials, natural stone, timber, weathering, granitoids.

\section{INTRODUCTION}

Construction industry is the second largest consumer of raw materials, after the food industry. It absorbs $25 \%$ of the timber and $40 \%$ of the aggregates (stone, gravel and sand) produced worldwide [1]. The production of construction materials also requires significant amounts of energy for the extraction, processing and transport of raw materials. This paper presents a research that starts by contextualize the construction industry in the north of Portugal, a densely populated area (Fig. 1(a)) and then explored how the use of less transformed materials and traditional techniques may be used to reduce environmental impacts. The north littoral region of Portugal is a highly populated part of the country (Fig. 1(a)). The use of weathering material seeks to harness

Manuscript received October 18, 2014; revised January 20, 2015. This work was supported in part by FCT (Fundação para a Ciência e Tecnologia, Portugal) and COMPETE (Programa Operacional de Factores de Competitividade, Portugal).

P. Mendonça is with University of Minho School of Architecture, Azurém Campus, 4800-058 Guimarães, Portugal (e-mail: mendonca@ arquitectura.uminho.pt).

B. Martins is with University of Coimbra, Geography Department, Largo da Porta Férrea, 3004-530 Coimbra, Portugal (e-mail: bruno.martins@uc.pt). geological feature of the region, especially the abundance of granitoid rocks, close to 50\% (Fig. 1(b) and Table I). Hesperian Massif (also called Old Massif, Iberian Massif or Hercynian Massif) is the morphostructural support of northern Portugal.

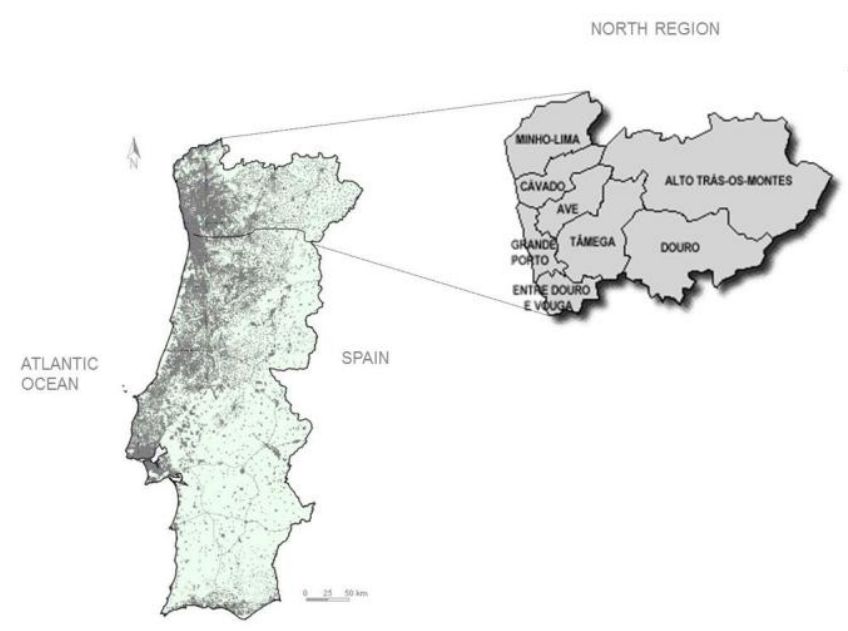

(a)

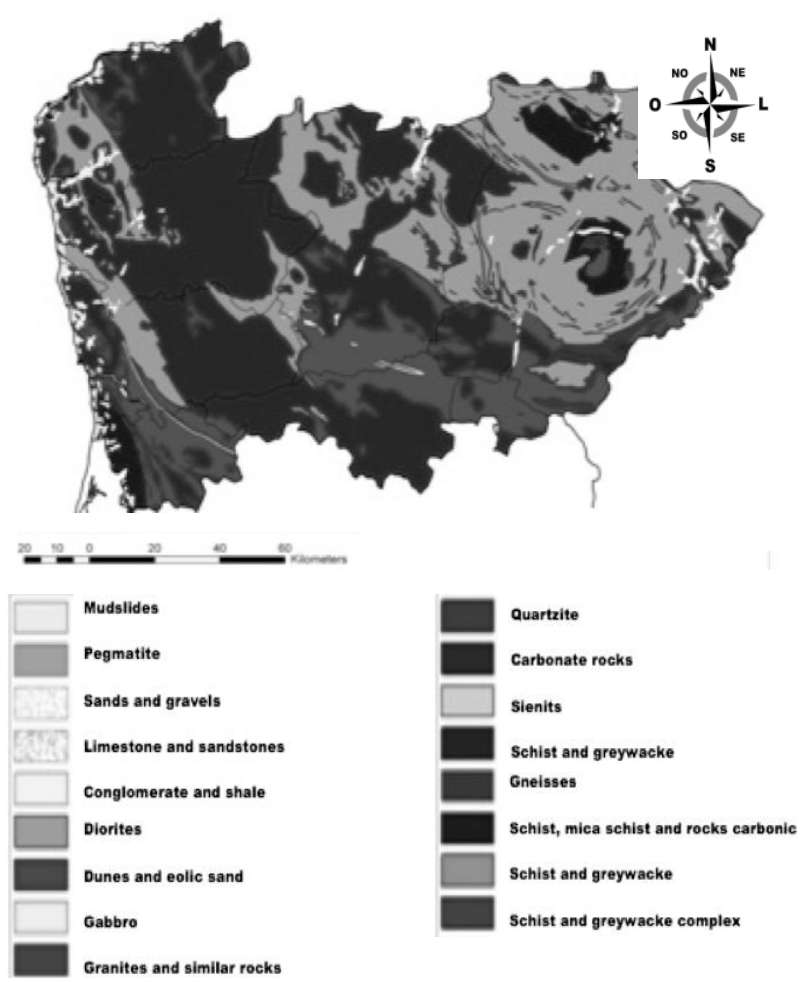

(b)

Fig. 1. The north region of Portugal: (a) demography and statistic regions of level III (adapted from INE), and (b) lithology (adapted from http://sniamb.apambiente.pt).

The Hesperian Massif consists of igneous and metamorphic ante-mesozoics rocks, consolidated especially 
during the Hercynian movements, responsible for an important regional metamorphism and for a sinorogenic magmatism [2], [3]. One of the characteristics of the CentraI Iberian Zone is the almost total absence of Precambrian. Thus, at the geological level, it can be highlighted the CXG, the quartzites of the Ordovician and also the different types of Hercynian granitoids (especially the granitoids of alkaline and calcoalcaline series) [4] that arise in very large patches in this region.

$\underline{\underline{\text { TABLE I: LITHOLOGY DISTRIBUTION IN THE NORTH REGION OF PORTUGAL }}}$

\begin{tabular}{|c|c|c|}
\hline \multirow{2}{*}{ LITHOLOGY } & \multicolumn{2}{|c|}{ Area } \\
\hline & $\mathrm{Km}^{2}$ & $\%$ \\
\hline Holocene alluviums & 62,41 & 0,29 \\
\hline Dunes and Holocene Eolic Sand & 85,95 & 0,40 \\
\hline Sands and Pleistocene Sediments & 217,32 & 1,02 \\
\hline $\begin{array}{c}\text { Fluvial and marine deposits, sandstones } \\
\text { with low degree of consolidation, } \\
\text { pliopleistocenic clays }\end{array}$ & 160,05 & 0,75 \\
\hline $\begin{array}{l}\text { Arcoses, sandstones, limestones } \\
\text { (Paleogene-Miocene) }\end{array}$ & 22,50 & 0,11 \\
\hline SEDIMENTARY ROCKS & 548,23 & $\mathbf{2 , 5 8}$ \\
\hline $\begin{array}{l}\text { Schists, amphibolites, mica schists, } \\
\text { greywackes, quartzites, carbonic rocks, } \\
\text { gneisses (pre-Cambrian) }\end{array}$ & 855,07 & 4,02 \\
\hline $\begin{array}{c}\text { Shale-greywacke complex (Precambrian to } \\
\text { the Cambrian) }\end{array}$ & 2967,22 & 13,95 \\
\hline $\begin{array}{l}\text { Carbonate rocks (from the Precambrian to } \\
\text { the Devonian marine facies) }\end{array}$ & 17,15 & 0,08 \\
\hline Quartzite (Ordovician to Devonian) & 932,10 & 4,38 \\
\hline $\begin{array}{c}\text { Shales and greywackes (the Ordovician to } \\
\text { the Silurian) } \\
\text { Shales, greywackes and sandstones } \\
\text { (Devonian to Carboniferous) }\end{array}$ & 5831,02 & 27,41 \\
\hline $\begin{array}{l}\text { Conglomerates, shales and carbonic schists } \\
\text { (Carboniferous to the Devonian) }\end{array}$ & 35,38 & 0,04 \\
\hline METAMORPHIC ROCKS & 10646,99 & 50,04 \\
\hline Pegmatites & 3,26 & 0,02 \\
\hline Diorites, hornblende and pyroxenite & 56,67 & 0,27 \\
\hline Gabbros & 9,55 & 0,04 \\
\hline Granites and similar rocks & 9969,93 & 46,86 \\
\hline MAGMATIC ROCKS & 10055,48 & 47,26 \\
\hline $\begin{array}{c}\text { Others } \\
\end{array}$ & 25,15 & 0,12 \\
\hline
\end{tabular}

\section{CONSTRUCTION INDUSTRY IN PORTUGAL}

A construction boom took place in Portugal during the 80s and 90s of the past century, most of buildings made without a sustainable cost/benefit ratio due to initial budget limitations, but also to a lack of knowledge and legislation concerning environmental questions. Nowadays, new quality constraints, especially related with the implementation of Energetic Certification, following European directive requirements, are conducting to relevant changes, especially regarding building thermal performance - and so to an increased quality of the exterior envelope. However, the legislation and concerns about environmental impacts related with the construction and demolition phases are still much neglected. In this paper, the environmental impacts related with the construction phase are assessed and a case study is presented, based on the viability of using opaque façade systems made in natural inorganic materials instead of the most common solution applied nowadays in Portugal - hollow brick.

\section{A. Hollow Brick}

Hollow brick is available in the Portuguese territory; however the industries are concentrated mainly in the littoral center of the country (Fig. 2(a)). The biggest production is concentrated along the central coastal strip, in the Lisbon and Tagus valley region, Aveiro and Leiria (Centre region) respectively, whose summed values represent the total national production, in an approximate percentage of $70 \%$. In 2000 Portugal was the $5^{\text {th }}$ biggest producer in Europe (in absolute number) and the $1^{\text {st }}$ if considered the production per-capita (Table II). The north of Portugal accounts for less than $7 \%$ of the total national brick production (Fig. 2(a)).

TABLE II: EUROPEAN PRODUCTION OF BRICK TOTAL AND PER-CAPITA IN 2000 (BY DECREASE ORDER)

\begin{tabular}{lccc}
\hline \hline & $\begin{array}{c}\text { Production in } \\
\text { 2000 (kt/year)* }\end{array}$ & $\begin{array}{c}\text { Inhabitants in } \\
2000 \text { (half of the } \\
\text { year)** } \times 1000\end{array}$ & $\begin{array}{c}\text { Production of } \\
\text { brick } \\
\text { per-capita } \\
\text { (kg/pers.year) }\end{array}$ \\
\hline 1- Italy & 15.169 & 57.530 & 264 \\
2- Germany & 11.339 & 82.017 & 138 \\
3- Spain & 11.037 & 39.910 & 277 \\
4- UK & 6.177 & 59.415 & 104 \\
5- Portugal & $\mathbf{4 . 7 3 5}$ & $\mathbf{1 0 . 0 1 2}$ & $\mathbf{4 7 3}$ \\
6- Hungary & 4.031 & 9.968 & 404 \\
7- Belgium & 3.183 & 10.249 & 311 \\
8- France & 2.976 & 59.238 & 50 \\
9- & 2.607 & 15.864 & 164 \\
Netherlands & 1.755 & 8.080 & 217 \\
10- Austria & P. & & 5 \\
\hline
\end{tabular}

Source: * TBE - European Brick and Tile Manufacturers' Federation [5]; ** U. S. Census Bureau - http://www.census.gov/

Percentage of holdings $(\%)$

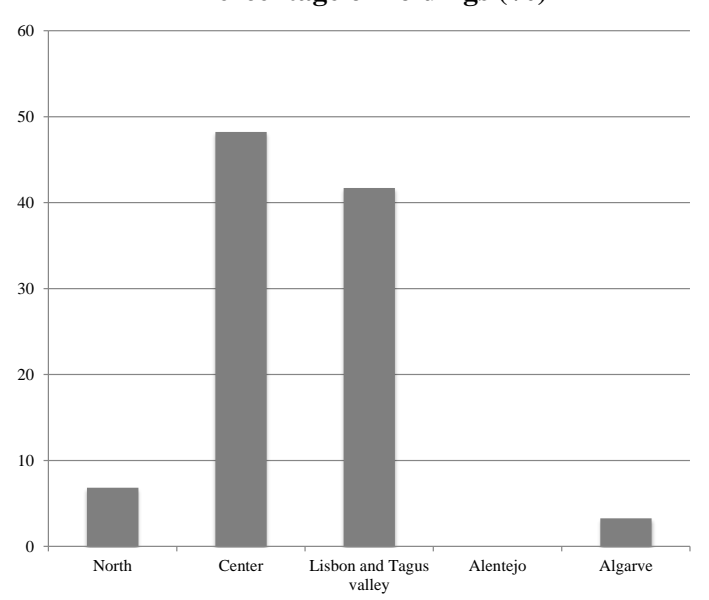

(a)

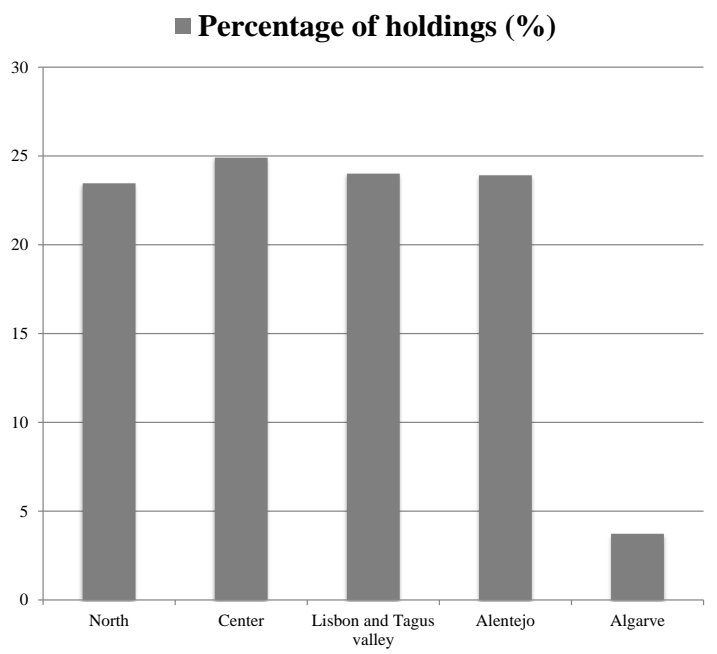

(b)

Fig. 2. Percentage of holdings of the Portuguese national total: brick (a) and stone (b) by NUTII. Adapted from LNEG - www.lneg.pt. 


\section{B. Stone}

Portugal is among the world's top ten natural quarry stone producers, as it can be seen on Table III. The output of the top ten quarry stone producing countries collectively accounted for $92.6 \%$ of world quarry stone output (107Mt) in 2009. If we consider the ratio between production and inhabitants, than Portugal is largely the biggest producer among the top ten producers, with almost $30 \mathrm{~kg} /$ person.year. North of Portugal produces a significant amount of quarry stone (Fig. 2(b)), especially granite and also schists, due to the natural presence of these elements on the soil (Fig. 1(b) and Table I).

TABLE III: QUARRY STONE PRODUCTION (BY DECREASE ORDER)

\begin{tabular}{lccc}
\hline \hline & $\begin{array}{l}\text { Production in } \\
\text { 2009 (kTon } \\
\text { /year)* }\end{array}$ & $\begin{array}{c}\text { Total population in } \\
\text { 2009 (half of the } \\
\text { year)** } \times 1000\end{array}$ & $\begin{array}{c}\text { Quarry stone } \\
\text { production } \\
\text { per-capita } \\
\text { (kg/person.year) }\end{array}$ \\
\hline 1- China & 2300,5 & 1.334 .740 & 1,7 \\
2- India & 2107,9 & 1.174 .000 & 1,8 \\
3- Turkey & 1155,6 & 70.538 & 16,4 \\
4- Iran & 1112,8 & 73.651 & 15,1 \\
5- Italy & 909,5 & 60.045 & 15,1 \\
6- Brazil & 749,0 & 191.481 & 3,9 \\
7- Spain & 716,9 & 45.828 & 15,6 \\
8- Egypt & 363,8 & 76.800 & 4,7 \\
9- Portugal & $\mathbf{3 1 0 , 3}$ & $\mathbf{1 0 . 6 2 7}$ & $\mathbf{2 9 , 2}$ \\
10- U.S.A. & 181,9 & 307.374 & 0,6 \\
\hline *http://www.hkexnews.hk/listedco/listconews/sehk/2011/0307/01380_101 & \\
7369/E114.pdf & \\
**http://www.indexmundi.com/ &
\end{tabular}

\section{Earth Construction}

In Portugal, the first earth houses (usually rammed earth) appeared about 2500 years ago. Earth construction generally uses granitoid weathering product associated with strong presence of tectonic faults and fractures, sometimes mixed with clay if necessary. Due to its abundant availability in the Portuguese territory, there is no industry associated with the exploration of earth as construction material. This material lasted until the mid-twentieth century in the construction of rural buildings [6]. It was characteristic of low income populations using traditional techniques and local labor. The adobe and rammed earth have poor resistance to the action of atmospheric agents in Portuguese climate because they crumble easily in the presence of rain or rising damp, so the earth walls could not sit directly on the ground, so these houses were traditionally based on foundations of stone or brick, rose above the ground. When more significant heights were needed, especially in urban context, the walls were reinforced in whole or in part, with a wooden skeleton embedded inside in order to increase the overall load bearing capacity of the wall and decrease its thickness. Two workers could build about $8 \mathrm{~m}^{3}$ in 12 hours, as long as the earth is available in the vicinity of the construction site [7]. This construction system was brought to a high degree of complexity in the case of the reconstruction of downtown Lisbon destroyed after an earthquake in 1755. Nowadays, with exception of a few examples in the south of Portugal, earth is not used as construction material.

\section{Characterization OF HOUSING DWELlingS IN NORTH OF PORTUGAL}

In the North of Portugal, the total area of licensed new housing dwellings has been decreasing in the last ten years. In 2012 it was $2.788 .317 \mathrm{~m}^{2}$, corresponding to an average area of $107 \mathrm{~m}^{2}$ per housing dwelling [8]. In this region, the average area of habitable compartments were $21,1 \mathrm{~m}^{2}$ in 2012 As in previous years, most building permits were for new construction, representing $63,8 \%$ of the buildings. In 2011 new construction accounted for $64,2 \%$ and in 2010 for $69,4 \%$, which shows the downward trend of new construction and the growing importance of refurbishing [8].

Following a previous study by Mendonça [9], it could be concluded that brick accounts for almost $40 \%$ of the Embodied Energy of all the materials used in a building construction (Fig. 3), and especially on exterior walls. Thus, for obtaining less environmental impacting housing solutions, the consideration of materials with less EE than brick should be pondered. That's the case of the traditional materials stone and earth, the solutions here proposed and analyzed in comparison with brick construction.

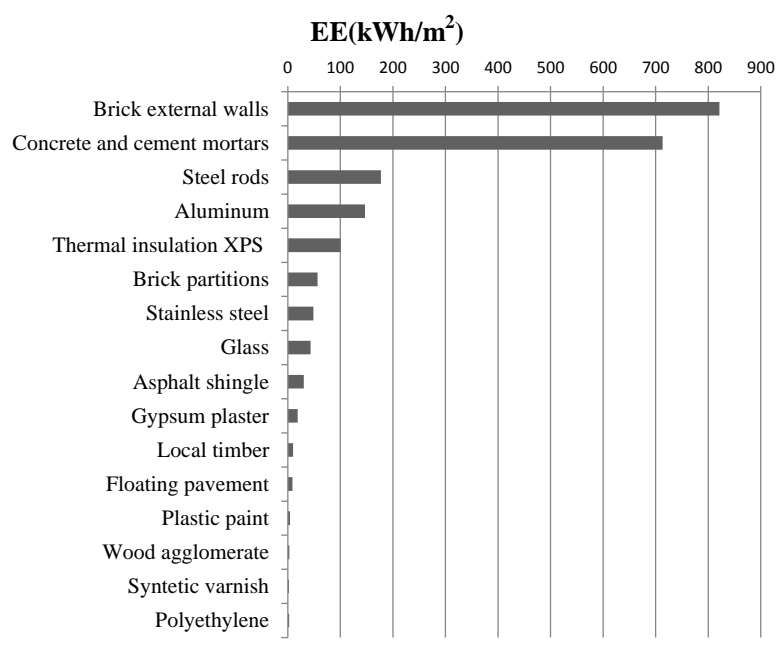

Fig. 3. Embodied energy of materials used in a typical Portuguese contemporary building [9].

\section{SYNTHESIS OF RESULTS}

Fig. 4 present sections of the exterior walls analyzed, with a summary of the properties with influence on the aspects of comfort and environmental impact. For this study it was considered that just the exterior walls would be changed. These walls present similar properties in terms of $U$ value and thermal mass. An increase in the U-value could be pondered for all the proposed solutions taking into account the future legal requirements that will increase significantly beyond 2015 in Portugal. As it should be applied to all the solutions in analysis in equal way, it wouldn't compromise the relative comparison. The acoustic insulation in all solutions responds to the present minimum legal requirements. The structure, dividing walls, windows and all other specifications of the test cell considered for the study were kept constant.

On Table IV are presented the estimated considered environmental indicators by $\mathrm{m}^{2}$ of useful pavement area of a building using different types of wall. This compartment, with $20 \mathrm{~m}^{2}$ (corresponding to the average area of a habitable compartment in Portugal) intends to represent a conventional housing building located in the littoral north of Portugal. The methodology considered for this study is described in detail 
by Mendonca in a previous study [10]. By the analysis of Table IV, it can be concluded that the use of adobe in the exterior walls of housing buildings allows a reduction of $36 \%$ in Embodied Energy, 30\% in Global Warming Potential, 28\% in Acid Potential and $83 \%$ in Chemical Oxygen Depletion in relation to the conventional hollow brick solution.

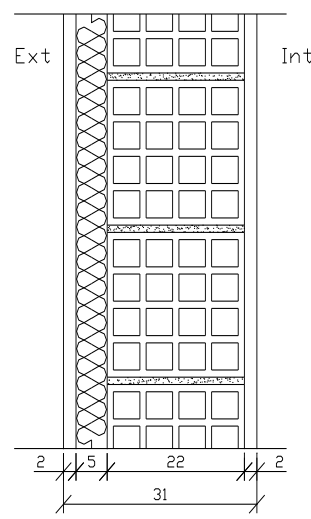

$\mathrm{U}\left(\mathrm{W} / \mathrm{m}^{2} \cdot{ }^{\circ} \mathrm{C}\right)=0,44$

$\mathrm{R}_{\mathrm{W}}(\mathrm{dB})=53$

(a) B22 - Hollow brick
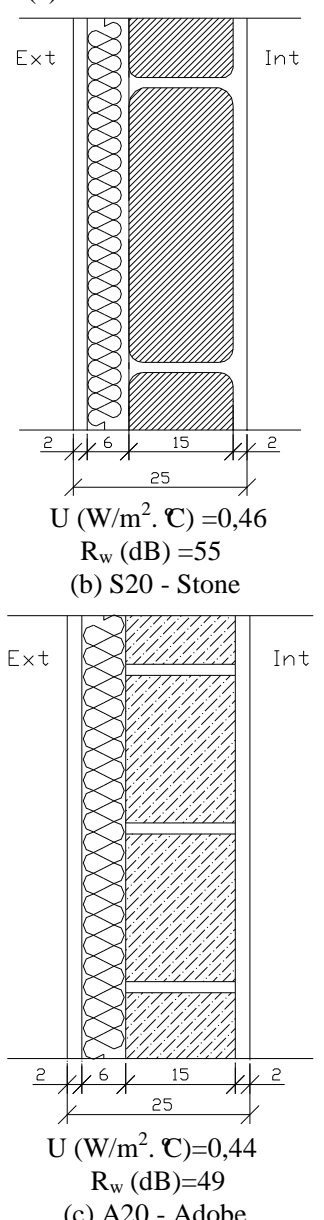

Fig. 4. Studied walls: (a) Simple hollow brick with external EPS insulation (ETIC system), (b) Simple stone masonry with external EPS insulation; (c) Simple adobe masonry with external EPS insulation.

The use of local stone allows a reduction of $33 \%$ in Embodied Energy, 29\% in Global Warming Potential, 28\% in Acid Potential and $83 \%$ in Chemical Oxygen Depletion. Both solutions are adequate to Portuguese thermal regulations, both in terms of $U$ value as in terms of acoustic insulation. Regarding all the environmental aspects considered, the exterior wall system using natural materials come out as more sustainable than the conventional solution in hollow brick. Considering the total area of housing construction in north of Portugal in 2012, the use of Adobe instead of hollow brick in the exterior walls, even keeping all other materials in the building, could allow an annual saving of almost 3,9 million MWh in Embodied Energy, 770 thousand Tons of equivalent $\mathrm{CO}_{2}$ in Global Warming Potential, 9,2 thousand Tons of $\mathrm{SO}_{2}$ in Acid Potential and 6,4 thousand Tons of $\mathrm{NO}_{\mathrm{x}}$ in Chemical Oxygen Depletion.

TABLE IV: ESTIMATED ENVIRONMENTAL INDICATORS OF A BUILDING WITH THE ANALYZED EXTERNAL WALL SOLUTIONS

\begin{tabular}{|c|c|c|c|c|c|}
\hline & $\begin{array}{c}\text { B22 } \\
\text { Hollow } \\
\text { brick }\end{array}$ & \multicolumn{2}{|c|}{$\begin{array}{c}\text { A20 } \\
\text { Adobe }\end{array}$} & \multicolumn{2}{|c|}{$\begin{array}{c}\text { A20 } \\
\text { Granite }\end{array}$} \\
\hline $\begin{array}{c}\text { Weight } \\
\left(\mathrm{kg} / \mathrm{m}^{2} \text { u.p.a.* }\right)\end{array}$ & 3034,0 & \multicolumn{2}{|c|}{3682,1} & \multicolumn{2}{|c|}{3332,1} \\
\hline$\left(\mathrm{kWh} / \mathrm{m}^{2}\right.$ u.p.a.* & 2187,6 & 1391,9 & $(-36 \%)$ & 1474,1 & $(-33 \%)$ \\
\hline $\begin{array}{c}\text { GWP** } \\
\left(\mathrm{g} / \mathrm{m}^{2} \text { u.p.a.*) }\right.\end{array}$ & 392408,4 & 276147,4 & $(-30 \%)$ & 278947,4 & $(-29 \%)$ \\
\hline $\begin{array}{c}\text { AP*** } \\
\left(\mathrm{g} / \mathrm{m}^{2} \text { u.p.a.* }\right.\end{array}$ & 4603,0 & 3299,2 & $(-28 \%)$ & 3299,2 & $(-28 \%)$ \\
\hline $\begin{array}{c}\mathrm{COD}^{* * * * *} \\
\left(\mathrm{~g} / \mathrm{m}^{2} \text { u.p.a.*) }\right.\end{array}$ & 13364,0 & 2281,7 & $(-83 \%)$ & 2281,7 & $(-83 \%)$ \\
\hline
\end{tabular}

* u.p.a.: useful pavement area; ** GWP - Global Warming Potential in grams of equivalent $\mathrm{CO}_{2}$; *** $\mathrm{AP}$ - Acid potential in grams of $\mathrm{SO}_{2}$; **** COD Chemical Oxygen Depletion in grams of $\mathrm{NO}_{\mathrm{x}}$; EE, GWP, AP and COD reference values adapted from Berge [1]

\section{REFERENCES}

[1] B. Berge, The Ecology of Building Materials, Architectural Press, Bath, 1999.

[2] A. Ribeiro and D. Sanderson, "SW Iberia, transpressional orogeny in the variscides," in EUROPROBE-Litosphere Dynamics, Origin and Evolution of Continents, D. G. Gee and H. J. Zeyen, Eds. Uppsala University, 1996, p. 138.

[3] A. Ribeiro, "The geodynamic evolution of Portugal," in Geology of Portugal in the Iberia Contexto," R. Dias, A. Araújo et al., Eds. University of Évora, 2006, pp. 1-27.

[4] J. J. Beetsma, "The late Proterozoic/Paleozoic and Hercynian crustal evolution of the Iberian Massif, N Portugal, as traced by geochemistry and $\mathrm{Sr}-\mathrm{Nd}-\mathrm{Pb}$ isotope systematics of pre-Hercynian terrigenous sediments and Hercynian granitoids," $\mathrm{PhD}$ thesis, Vrije Universiteit Amsterdam, 1995.

[5] P. Minoliti, "The European brick and tile industry," Brick World Review, no. 1, pp. 24-29, 2002.

[6] E. Veiga de Oliveira and E. F. Galhano, Portuguese Traditional Architecture (in portuguese), 4th ed. Publicações D. Quixote, Lisboa, 2000.

[7] F. Pinho, Old Buildings Walls in Portugal (in portuguese), LNEC, Lisboa, 2000.

[8] INE, Statistics of Construction and Housing in Portugal 2012, INE, 2013.

[9] P. Mendonca, "Living under a second skin — Strategies for the environmental impact reduction of solar passive constructions in temperate climates," PhD thesis, University of Minho, 2005.

[10] P. Mendonça and L. Bragança, "Sustainable housing with mixed weight strategy - A case study," Building and Environment, vol. 42, iss. 9, pp. 3432-3443, September 2007.

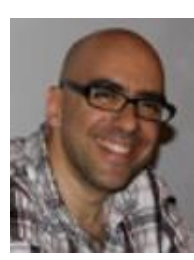

Paulo Mendonça was born in Porto in June 10. He got the $\mathrm{PhD}$ degree in civil engineering from the University of Minho with the thesis "Living under a second skin" in 2005. With a PhD fellowship of Portuguese Foundation for Science and Technology, he got the "advanced studies diploma" in Barcelona on the Technical Superior School of Architecture. He was a JNICT fellowship student in the Textile Engineer Department of the University of Minho, where he obtained the master degree defending a thesis about "Intelligen textiles in architecture" in 1997. He graduated in architecture from the 
University of Porto, Portugal in 1994. He was an Erasmus granted student in ETSAB, Barcelona.

$\mathrm{He}$ is an associate professor in the Architecture School of the University of Minho, Portugal (EAUM), the president of EAUM from 2011 to 2012 and the vice-president from 2010 to 2011; the architectural graduate and integrated master studies director from 2005 to 2009; the author of more than one hundred publications. His research is in six concluded research projects. He is the author of three patents of invention. Since 1995, he started in the specialization field of "architectural membranes", progressively devoting his research interests to the area of building physics. The main research subjects includes lightweight and mixed weight buildings, low cost housing, local and global economic asymmetries, low-tech strategies, energy costs and sustainable development, new materials and technologies, recycling and reusing potentialities.

Prof. Mendonça is a member of the Portuguese Board of Architects, representative member on the "Portuguese commission of energetic and air quality certification system of buildings".

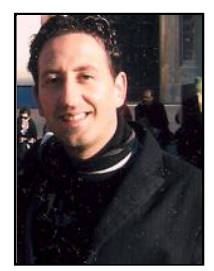

Bruno Martins was born in Porto in April 11. He got the $\mathrm{PhD}$ degree in physical geography from the University of Coimbra with the thesis "A depressão de Chaves-Régua-Verin: contributo para a análise do risco de ravinamento (Régua-Chaves-Verin depression: contribute for gully hazards analysis" in 2010 . He is a professor of the Geography Department of the University of Coimbra, Portugal and researcher in Centro de Estudos em Geografia e Ordenamento do Território CEGOT (Center of Geography and Planing Studies) of Coimbra, Minho and Oporto University, the author of several publications including: books, papers on journals, book chapters and papers in proceedings books with peer review. Throughout the recent years, he has developed researches in geomorphology, natural hazards and natural resources in the central and northern region of Portugal and Cape Verde. 